Agro-Science Journal of Tropical Agriculture, Food, Environment and Extension Volume 11 Number 2 May 2012 pp 46 - 53

ISSNIIIY-7455

\title{
NITROGEN MINERALIZATION KINETICS AND PARAMETER ESTIMATES IN SOIL AMENDED WITH NEEM SEED CAKE AND INORGANIC FERTILIZER IN SAMARU, NIGERIA
}

\author{
Mohammed $^{1}$, K. O., Oyinlola ${ }^{2}$, E. Y., Uyovbisere ${ }^{2}$, E.O., and Odunze ${ }^{2}$, A. C. \\ ${ }^{I}$ Soil, Water and Material Testing Laboratory, Services Department, Lower Niger River \\ Basin Development Authority, Ilorin, Kwara State, Nigeria. \\ ${ }^{2}$ Dept. of Soil Science, Institute for Agricultural Research, Ahmadu Bello University, \\ Zaria. \\ *Correspondence Author: Kehinde O. Mohammed
}

\begin{abstract}
A field study was conducted to assess the effect of neem seed cake (NSC) on the kinetics of net nitrogen mineralization and parameter estimates. The experiment consisted of sorghum plots to which milled NSC (with \% $>3$ ) and urea (inorganic $N$ source) were applied. Ammonium-nitrogen and nitrate-nitrogen were determined after $0,2,4,6,8,12,19$ and 34 weeks from soils covered with $P V C$ tubes inserted into the sixteen treatment combination plots. Inorganic $N$ concentration in the amended plots and the control were analysed using five mathematical $N$ mineralization models. $N_{b}$, $N_{e}, h$ and $k$ were estimated from the fit of each mathematical model. The treatments were highly variable in their respective $N$ mineralization characteristics, but the peaks for mineralized $N$ content were observed at early incubation periods, $i$. e., $10-28$ days. Potential respective mineralizable $N\left(N_{0}\right)$ content of the first order rate, consecutive $(h \neq k)$, consecutive $(h=k)$, Gompertz and mixed order rate constant was $-927 \mathrm{E}-22,430.90,1.9 E-21,568.40$ and $427.20 \mathrm{mg} \mathrm{kg}^{-1}$ soil and the respretively rate constant $(k)$ was $-5 E+21,0.2269,2 E+23,0.0954$ and 0.8116 .respretively Net $N$ mineralization was best described by a mixed order rate model $\left(R^{2}=0.992\right)$ and residual mean square error $(R M S E)$ was $=28.41$. A Gompertz function also fitted the data closely $\left(R^{2}=0.999 ; R M S E=52.47\right)$. The two models recognize that $N$ mineralization is not just a function of substrate $N$ concentration but also of the capacity of the microbial community to adjust to substrate quality and composition affecting their growth and activity.
\end{abstract}

Key words: mineralization model, neem seed cake, $\mathrm{N}$ mineralization, parameter estimates, PVC tubes

\section{INTRODUCTION}

Good management of agricultural production systems such as soil resources is a response to challenges posed by world food crisis. Lately, the use of local and readily available organic residues as soil amendment in sub-Saharan Africa to improve soil fertility and organic matter status is rapidly gaining widespread support (Agbenin et al., 1999). It is pertinent therefore to exploit and evaluate the potentials of locally available organic wastes as soil amendments in the effort towards sustainable soil management with low external input.

The neem tree, Azadirachta indica (dongoyaro), offers great potential for agricultural, industrial, and commercial exploitation, and is potentially one of the most valuable of all arid-zone trees. It shows promise for pest control, reforestation, and improving human health (Vietmeyer, 1992). The neem foliage and neem seed cake (NSC) have been demonstrated to have high soil fertilization potential, particularly with respect to nitrogen release (Radwanski, 1969; Kethar, 1974; Kethar and Kethar, 1995; Idris et al., 1995; Agbenin et al., 1999 and 2008; Uyovbisere et al., 1999). Consequently, it could be one panacea for the maintenance of soil fertility for sustained crop production which is a major challenge facing agriculture and food security in Nigeria and most other developing countries (Mokwunye, 1991; Murwira et al., 2002). 
However, the major concern in the continuous or the abundant application of NSC is the behaviour of organic nitrogen that penetrates the soil; on eventual decomposition, the available $\mathrm{N}$ and excess nitrate $\left(\mathrm{NO}_{3}\right)$ is leached into the ground water and contaminates it or is released into the air. To minimize these effects, the amount of neem seed cake used should be fine-tuned in accordance with its ability to release the available N. For NSC to fulfill the nutrient requirements of a crop, information on the amount of nutrients mineralized following application is considered necessary. Consequently, an accurate prediction of the amount of inorganic nitrogen that would be released from the soil on amendment with NSC is essential in the development of farming practices for maximizing $\mathrm{N}$-use efficiency, minimizing negatives effects of $\mathrm{N}$ on the environment, improving crop quality and increasing crop production.

Previous studies on NSC mineralization in the northern guinea savanna of Nigeria (Samaru) are limited and have reported the $\mathrm{N}$ mineralization from laboratory studies (Agbenin et al., 1999, 2008; Garba, 2010). Laboratory studies have shown that NSC increased the soil exchange acidity and decreased the soil $\mathrm{pH}$ (Agbenin et al., 2008). Studies on the reactions of NSC under field conditions are scarce.

Nutrient mineralization patterns during decomposition of organic materials are related to the chemical composition or quality of the organic inputs (Heal et al., 1997) climatic conditions, soil physicochemical environment, and the nature of the soil organisms (Swift et al., 1979). Consequently, the kinetic dynamics of $\mathrm{N}$ in the field to determine its availability from NSC is necessary to ensure that this material will provide sufficient fertilization to the growing crop and cause minimal environmental degradation. Thus, a field mineralization study using PVC tubes was used to evaluate nitrogen mineralization of NSC at four levels.

\section{MATERIALS AND METHODS}

The study was conducted on the experimental site of the Institute for Agricultural Research Farm, Zaria in the Northern Guinea Savanna of Nigeria, whose soil characteristics are presented in Table 1. The experiment was conducted in a randomized complete block design replicated thrice with the plots measuring $6 \times 4.5 \mathrm{~m}$. The test crop was (sorghum bicoior)- Samsorg 17 (SK-5912). The organic material, NSC was obtained from the National Research Institute for Chemical Technology, Basawa-Zaria and incorporated into the soil two weeks before the planting to a depth of $0.15 \mathrm{~m}$ at four different levels: $0,1,2$, and 4 tonnes ha $^{-1}$ corresponding to
0, 38.5, 77 and $154 \mathrm{~kg} \mathrm{~N}^{-1}$. Some chemical properties of the NSC used are presented in Table 2.

\section{Analytical Methods \\ In situ mineralization procedure}

An in-situ covered-core method (Knoepp and Swank, 1995; Raison et al., 1987) was employed to measure $\mathrm{N}$ mineralization in 2010. Soil samples were taken at 2-week intervals beginning in June and ending in October. At each sampling, each of four open-ended PVC tubes $(0.25 \mathrm{~m}$ long with a diameter of $0.10 \mathrm{~m})$ were inserted $0.20 \mathrm{~m}$ into the ground midway between sorghum rows. The prctaces were then and capped. Soil samples were taken from within the tube (these were referred to as incubated samples) and also from outside the tube (these were referred to as ambient samples). There were 7 sampling dates (T1 to T7) plus an initial background measurement (T0). The initial soil sampling was conducted concurrently with the bulk sampling for estimating rainy season soil residual $\mathrm{N}$; however, incubation tubes were not set up at that time for T1 so as to allow for the incubation of the NSC that was incorporated until after two weeks when TB (1) samples were collected and tubes inserted for T2. When soil samples were taken from $\mathrm{T} 1$ to $\mathrm{T} 7$, a new set of incubation tubes were inserted adjacent to the previous ones midway between sorghum rows for the next sampling time. The time schedule for sampling was concurrent with field operations, with T1 sampling at the time of planting and $\mathrm{T} 7$ during harvest.

All soil samples were immediately distilled off with magnesium oxide and devarda alloy into $2 \%$ boric acid and distillates titrated with $0.025 \mathrm{~N} \mathrm{H}_{2} \mathrm{SO}_{4}$ for the corresponding $\mathrm{NH}_{4}{ }^{+}$ $-\mathrm{N}$ - and $\mathrm{NO}_{3}{ }^{-}-\mathrm{N}$ respectively. Total mineral-N $\left(\mathrm{NH}_{4}{ }^{+}\right.$and $\left.\mathrm{NO}_{3}^{-}\right)$were determined through summation. Cumulative mineralized $\mathrm{N}$ ( $\mathrm{N}_{\text {cum }}$ ) was calculated as the summation of mineralized $\mathrm{N}$ from planting to time $\mathrm{j}$ :

$$
\mathrm{N}_{\text {cum }}\left(\mathrm{kg} \mathrm{ha}^{-1}\right)=\sum \mathrm{N}_{\min \mathrm{j}}
$$

\section{Estimating potentially mineralizable $\mathbf{N}$}

The cumulative $\mathrm{N}$ mineralized at time $t\left(N_{\min }\right)$ was calculated from the first-order rate model (Stanford and Smith, 1972). Similarly, the nutrient release rate constants, $k$ were estimated from several other nonlinear equations (eq. iii to vi). These are the kinetic expressions (Andren and Paustian, 1987) which consist of consecutive reaction models (eq. iii and iv); a Gompertz function (eq. v) and a mixed-order rate model (eq. vi). The results of which were tested along with the conventional first-order rate mineralization model (eq.ii).

$\mathrm{N}_{\min }=\mathrm{N}_{\mathrm{o}}\left(1-\mathrm{e}^{-\mathrm{kt}}\right)+\mathrm{N}_{\mathrm{e}}$ 
Where $\mathrm{N}_{\mathrm{o}}$ is potentially mineralizable $\mathrm{N}, k$ is the rate constant, $\mathrm{N}_{\min }$ is cumulative $\mathrm{N}$ mineralized at time $t$, while $\mathrm{N}_{\mathrm{e}}$ is an additional term introduced to accommodate the initial rapid $\mathrm{N}$ flush (Jones, 1984).

$\mathrm{N}_{\min }=\mathrm{N}_{\mathrm{o}}-\mathrm{N}_{\mathrm{o}}\left(\mathrm{ke}^{-\mathrm{ht}}-\mathrm{he}^{-\mathrm{kt}}\right) /(\mathrm{k}-\mathrm{h})$ (Noggle, 1985)

$\mathrm{N}_{\min }=\mathrm{N}_{\mathrm{o}}-\mathrm{N}_{\mathrm{o}} \mathrm{e}^{-\mathrm{kt}}(\mathrm{kt}+1)$

$\mathrm{N}_{\text {min }}=\mathrm{N}_{\mathrm{o}}-\mathrm{N}_{\mathrm{o}} \mathrm{e}^{-\mathrm{he}-\mathrm{kt}}-\mathrm{N}_{\mathrm{o}} \mathrm{e}^{-\mathrm{h}}$

(France and Thornley, 1984)

$\mathrm{N}_{\min }=\mathrm{N}_{\mathrm{o}}\left(1-\mathrm{e}^{-\mathrm{kt}-0.5 \mathrm{ht} 2}\right)$

Where $h$ is an additional coefficient in eq. iii and vi. All other terms are as defined for eq. (ii). The consecutive reaction models (eq. iii and iv) describe a mineralization reaction in which reactants pass through an intermediary to form the products. The conversion of reactants to the intermediary and from the intermediary to products is assumed to follow first-order rate kinetics with rate constants $h$ and $k$ respectively. A special case of the model is to allocate equal rates to the formation of intermediary and products $(h=k)$, in which case $\mathrm{N}$ mineralization can be described by a single rate constant (eq.iv). Diaz-Firroz et al. (1988) applied a consecutive reaction model to describe the kinetics of $\mathrm{N}$ mineralization from cattle slurry incorporated into a soil.

A Gompertz function (eq.v), an asymmetric logistic growth model, was also applied to $\mathrm{N}$ mineralization (Ellert and Bettany, 1988; Agbenin et al., 1999). The mixed-order model (eq. vi), recognizes a single mineralizable substrate pool conforming to both first- and second-order rate kinetics (Brunner and Focht, 1984).

\section{Statistical analysis}

A nonlinear method was used to fit experimental data to mineralization models tested in the study. The SAS non-linear regression models were employed to compare rates of net $\mathrm{N}$ mineralization; Coefficient of multiple determinations $\left(\mathrm{R}^{2}\right)$; Coefficient of Variation (CV) and the root mean square error (RMSE) were computed to assess the goodnessof-fit statistics of the models used. The RMSE was calculated as follows:

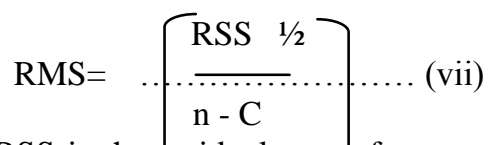

Where RSS is the esidual sum of squares, $\mathrm{n}$ is the number of observation points and $\mathrm{C}$ is the number of coefficients in a model.

\section{RESULTS AND DISCUSSION $\mathrm{N}$ mineralization patterns}

The cumulative $\mathrm{N}$ mineralized after 34 weeks of incubation using PVC tubes in the field in the year is presented in Figure 1. The cumulative $\mathrm{N}$ mineralization with time showed an initial rapid rate in the first six weeks after incubation followed by slower release.later The $\mathrm{N}$ mineralization pattern showed that the $\mathrm{NO}_{3}{ }^{-}-\mathrm{N}$ fraction in the soil far exceeded the $\mathrm{NH}_{4}{ }^{+}-\mathrm{N}$ fraction, the formeraccounting for $64 \%$ of the $\mathrm{N}$ mineralized from neem seed cake.( NSC) The high nitrification rates recorded could be attributed to the retardation effect of neem residues on nitrification which is due to their active ingredient azadirachtin and other di- and triterpenoidal compounds which are toxic to nitrifying bacteria (Singh et al., 1991).

The amounts of $\mathrm{NH}_{4}{ }^{+}-\mathrm{N}$ mineralized generally increased throughout the period indicating progressive mineralization with time. The mean amounts of $\mathrm{N}$ mineralized was lower in the control than in the other treatments except in the $1 / 4$ recommended rates (RR) of NPK fertilizer for sorghum with a mean total inorganic $\mathrm{N}$ of $56.76 \mathrm{mg} \mathrm{kg}^{-1}$ (Table 3). Also, there was no significant difference in the mean inorganic $\mathrm{N}$ mineralized from plots that received NSC treatments alone and the control which recorded the lowest quantity when compared to the other treatments (Table 3). There were no significant differences among the interactions across all sampling dates (Table 3). This was in accordance with the findings of Adegbite and Olayinka (2010) who attributed the no significant difference between NPK and organic amended treatments to $\mathrm{N}$ immobilization. 


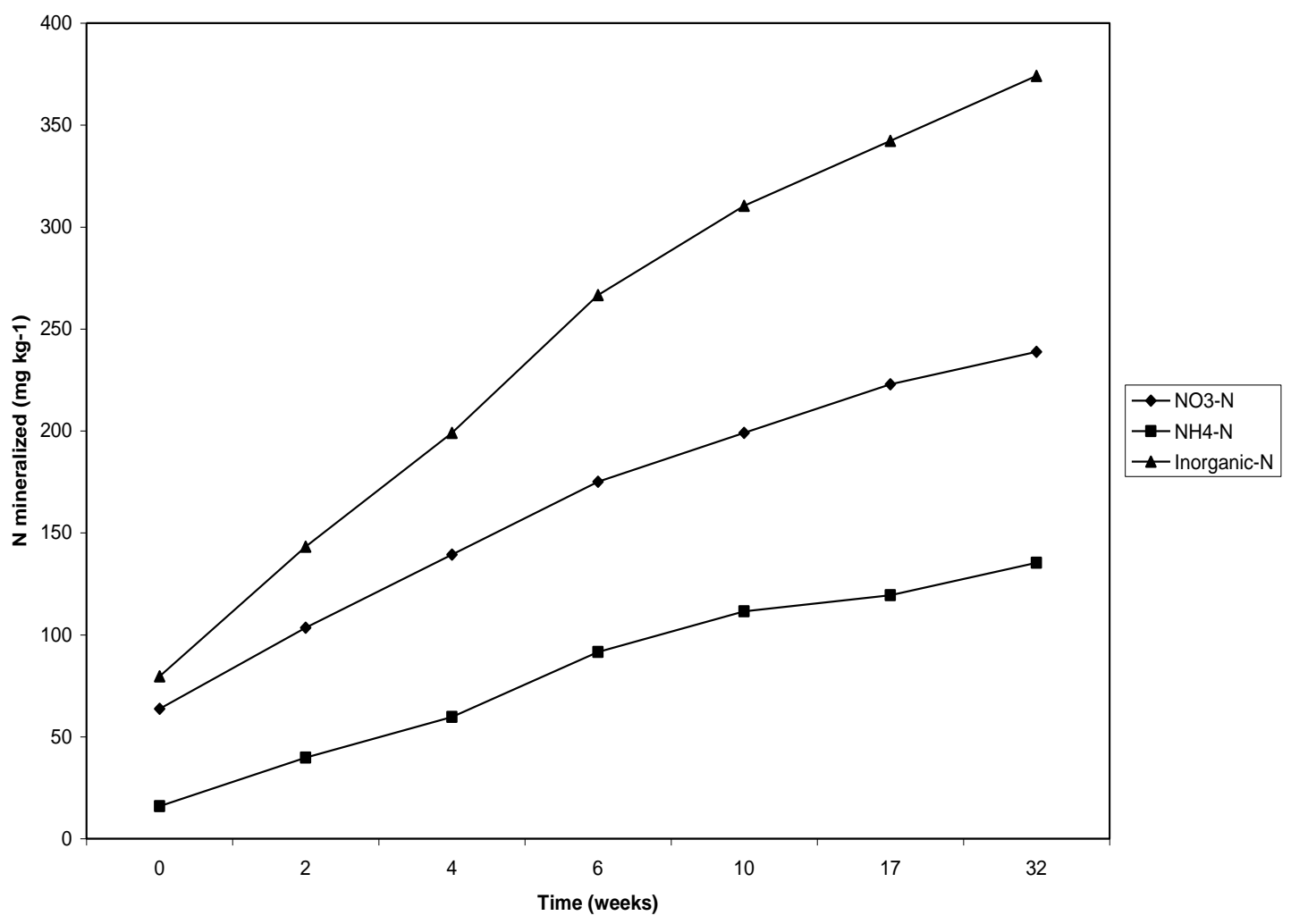

Figure 1: Cummulative total inorganic N, ammonium-N and nitrate-N from field incubation studies using PVC tubes in 2010

\section{$\mathrm{N}$ mineralization model}

Potential $\mathrm{N}$ mineralization, which is one of the many $\mathrm{N}$ availability indices (Keeney, 1982), as estimated by five mathematical models, and is presented in Table 4 for sixteen treatment combinations used in this study. Using the goodness-of-fit statistics, the data for net $\mathrm{N}$ mineralization pattern from NSC was best described by a mixed order rate equation (Eq. vi) compared with the first-order model equation (Eq. ii) advocated by Stanford and Smith (1972) or the consecutive $(h \neq k) ;(h=k)$ and the Gompertz function (Table 4) judging from the RMSE value. The consecutive reaction model with an additional parameter $\mathrm{h}$ was not superior to its simpler form with a single rate constant $(h=k)$. The simple consecutive reaction model with a single rate constant $(h=k)$ gave a better fit to inorganic $\mathrm{N}$ release pattern judging from its coefficient of variation $(36.3 \%)$ as against the negative $(-5.58 \%) \mathrm{CV}$ of the latter (Table 4 ).

From the goodness-of-fit statistics, the $\mathrm{N}$ mineralization from NSC was best described by a mixed order rate model $\left(\mathrm{R}^{2}=0.992\right.$; $\mathrm{RMSE}=$
28.4) compared with the first-order model equation (eq. i) $\left(\mathrm{R}^{2}=0.9827\right.$; $\left.\mathrm{RMSE}=397\right)$ advocated by Stanford and Smith (1972) or the consecutive models (eqs. iii and iv) (Table 4). The Gompertz function also recorded close $\left(\mathrm{R}^{2}=\right.$ 0.999; RMSE $=52.47$ ) value with the mixed order rate model and could also be used in predicting of potentially $\mathrm{N}$ mineralized from NSC. This corroborates the findings of Agbenin et al. (1999) that the Gompertz and mixed order rate models gave the best fit in their laboratory study using same organic material. The $\mathrm{N}$ mineralization pattern was not adequately described by a first-order rate equation compared to the other models, because mineralization from NSC was not simply a function of substrate $\mathrm{N}$ concentration in the organic material, a fundamental assumption of a first-order rate model (Stanford and Smith, 1972; Jones, 1984; Agbenin et al., 1999). Its negative $\mathrm{N}_{0}$ value (Table 4) indicated a lag in $\mathrm{N}$ mineralization arising from immobilization by microbial biomass early in the decomposition or mineralization process (Agbenin et al., 1999). 
Table 1: Physico-chemical characteristics of the soil of the experimental site, at Samaru

\begin{tabular}{ll}
\hline Soil property & Amount in soil \\
\hline Particle sizes $\left(\mathrm{g} \mathrm{kg}^{-1}\right)$ & 160 \\
$\mathrm{Clay}$ & 240 \\
$\mathrm{Silt}$ & 600 \\
$\mathrm{Sand}$ & Sandy loam \\
Textural class & 6.0 \\
$\mathrm{pH}\left(\mathrm{H}_{2} \mathrm{O} ; 1: 2.5 \mathrm{w} / \mathrm{v}\right)$ & 5.3 \\
$\mathrm{pH}\left(0.01 \mathrm{M} \mathrm{CaCl}_{2} ; 2.5 \mathrm{w} / \mathrm{v}\right)$ & 0.37 \\
$\mathrm{Bray}-1 \mathrm{P}\left(\mathrm{mg} \mathrm{kg}^{-1}\right)$ & 4.41 \\
Organic Carbon $\left(\mathrm{g} \mathrm{kg}^{-1}\right)$ & 5.25 \\
Total N $\left(\mathrm{g} \mathrm{kg}^{-1}\right)$ & \\
Exchangeable cations $\left(\mathrm{cmol} \mathrm{kg}^{-1}\right)$ & 0.21 \\
$\mathrm{~K}$ & 2.20 \\
$\mathrm{Ca}$ & 0.65 \\
$\mathrm{Mg}$ & \\
$\mathrm{Na}$ & 0.32 \\
Exchangeable acidity $\left(\mathrm{cmol} \mathrm{kg-}^{-1}\right.$ & \\
Extractable micronutrients $\left(\mathrm{mg} \mathrm{kg}^{-1}\right)$ & 5.00 \\
$\mathrm{Zn}$ & 24.29 \\
$\mathrm{Fe}$ & 1.50 \\
$\mathrm{Cu}$ & 3.06 \\
$\mathrm{Mn}$ & 5.20 \\
$\mathrm{Cation}$ exchange capacity $\left(\mathrm{cmol} \mathrm{kg}^{-1}\right)$ & 3.58 \\
Effective cation exchange capacity $\left(\mathrm{cmol} \mathrm{kg}^{-1}\right)$ & 0.20 \\
\hline
\end{tabular}

Table 2: Selected chemical characteristics of the neem seed cake used in the firsy and second years of the study for

\begin{tabular}{llll}
\hline Parameter & & $\mathbf{2 0 0 9}$ & $\mathbf{2 0 1 0}$ \\
\hline $\mathrm{N}$ & $\mathrm{g} \mathrm{kg}^{-1}$ & 38.50 & 53.40 \\
$\mathrm{P}$ & $\mathrm{g} \mathrm{kg}^{-1}$ & 3.70 & 1.80 \\
$\mathrm{~K}$ & $\mathrm{~g} \mathrm{~kg}^{-1}$ & 14.70 & 10.00 \\
$\mathrm{Ca}$ & $\mathrm{g} \mathrm{kg}^{-1}$ & 0.14 & 0.14 \\
$\mathrm{Mg}$ & $\mathrm{g} \mathrm{kg}^{-1}$ & 0.02 & 0.02 \\
$\mathrm{OC}$ & $\mathrm{g} \mathrm{kg}^{-1}$ & 230.50 & 300.20 \\
Lignin & $\mathrm{g} \mathrm{kg}^{-1} \mathrm{DM}$ & 30.10 & 44.67 \\
Cellulose & $\mathrm{g} \mathrm{kg}^{-1} \mathrm{DM}$ & 303.97 & 316.33 \\
Polyphenol & $\mathrm{g} \mathrm{kg}^{-1}$ & 13.30 & 8.00 \\
$\mathrm{C}: \mathrm{N}$ & & 5.99 & 5.62 \\
$\mathrm{~N}: \mathrm{P}$ & & 4.53 & 12.71 \\
$\mathrm{C}: \mathrm{P}$ & & 27.12 & 71.48 \\
$\mathrm{C}: \mathrm{N}: \mathrm{P}$ & & 0.70 & 1.34 \\
$\mathrm{~N}: \mathrm{C}$ & & 0.17 & 0.18 \\
Lignin: N & & 0.78 & 0.84 \\
Lignin: Cellulose & & 0.10 & 0.14 \\
Lignin: Polyphenol & & 2.26 & 5.58 \\
Cellulose: N & & 7.90 & 5.92 \\
Cellulose:Polyphenol & & 22.85 & 39.54 \\
Lignin: Cellulose: Polyphenol & & 0.01 & 0.02 \\
$\mathrm{~N}$ - P - K & & 0.26 & 1.06 \\
pH water & & 5.20 & 4.00 \\
pH & & 4.80 & 3.90 \\
\hline OC - organic & & & \\
\hline
\end{tabular}

OC- organic carbon; DM- dry matter 
The mineralization rate constant $(k)$ of the five mathematical models displayed a wide range from $-5 E+21$ to $2 E+23$ week $^{-1}$ and this may be attributed to the ability of each model to account for early $\mathrm{N}$ mineralization. Agbenin et al. (1999) reported comparatively lower $\mathrm{k}$ values for neem seed residue $\mathrm{N}$ mineralization in a laboratory incubation study $(0.046,0.204,0.076,0.094$ and -0.002) for the five models respectively. The disparity in the $k$ values obtained from earlier study with the same organics could be attributed to the fact that $\mathrm{N}$ released during incubation is derived from rather ill-defined and variable organic N sources (Harmsen and Van Shreven, 1955). As a result of field temperature fluctuations, Carlyle and Malcoln (1986) found greater rates of net $\mathrm{N}$ mineralization for laboratory incubated soil samples than for in-situ samples. These pools are however, replenishable under field conditions as a result of inputs of organic $\mathrm{N}$ from root and above-ground litter and the slow transformation of the more resistant pools of soil organic N. Thus, laboratory measures of mineralization especially on undisturbed soils can be an unreliable index of field rates (Lamb, 1980; Hart and Binkley, 1985). Also, measurements of $\mathrm{N}$ mineralization under controlled laboratory conditions provide an estimate of the pools of mineralizable $\mathrm{N}$ present at the time of sample collection (Raison et al., 1987). However, the $K$ value of the Gompertz model (0.095) was almost at par with the 0.0904 reported by Agbenin et al. (1999) in their laboratory study.

Table 3: Pattern of Inorganic N Mineralization ( $\mathrm{mg} \mathrm{kg}^{-1}$ ) by NSC and NPK treatment over a period of 3 weeks of sorghum growth in the field in 201

\begin{tabular}{|c|c|c|c|c|c|c|c|c|}
\hline \multicolumn{2}{|l|}{$\leftarrow$} & \multicolumn{3}{|c|}{ Sampling Period (weeks) } & \multicolumn{3}{|c|}{$\rightarrow$} & \multirow[b]{2}{*}{ Mean Total } \\
\hline Treatment & 2 & 4 & 6 & 8 & 12 & 19 & 34 & \\
\hline NPK kg ha-1 $(\mathrm{N})$ & & & & & & & & \\
\hline 0 & 92.51 & 66.67 & 64.01 & 62.69 & 56.72 & 54.73 & 31.18 & 61.27 \\
\hline $1 / 4 \mathrm{RR}$ & 85.57 & 61.03 & 59.70 & 59.04 & 55.72 & 49.75 & 26.53 & 56.76 \\
\hline $1 / 2 \mathrm{RR}$ & 97.51 & 67.66 & 65.34 & 64.34 & 59.04 & 52.74 & 32.50 & 62.73 \\
\hline FRR & 90.88 & 68.66 & 62.69 & 65.01 & 63.02 & 54.06 & 34.49 & 62.69 \\
\hline \multicolumn{9}{|l|}{ NSC tonne ha- ${ }^{-1}(\mathrm{~S})$} \\
\hline 0 & 84.91 & 61.03 & $52.40 \mathrm{~b}$ & 58.37 & 63.35 & 51.74 & 33.83 & 57.95 \\
\hline 1 & 84.92 & 65.34 & $60.03 \mathrm{ab}$ & 66.33 & 57.38 & 53.07 & 33.83 & 60.13 \\
\hline 2 & 100.83 & 69.65 & $66.33 \mathrm{ab}$ & 60.36 & 55.39 & 50.75 & 27.20 & 61.50 \\
\hline 4 & 96.18 & 67.99 & $72.97 \mathrm{a}$ & 66.00 & 58.37 & 55.72 & 29.85 & 63.87 \\
\hline $\begin{array}{c}\mathrm{SE} \pm \\
\text { Interaction }(\mathrm{N} \times \mathrm{S})\end{array}$ & 8.08 & 3.18 & 6.26 & 3.36 & 3.83 & 2.99 & 3.69 & 1.95 \\
\hline NXS & NS & NS & NS & NS & NS & NS & NS & NS \\
\hline
\end{tabular}

Table 4: Goodness-of-fit statistics and parameter estimates of five mathematical models fitted to inorganic $\mathbf{N}$ mineralized from neem seed cake incorporation

\begin{tabular}{lllccccc}
\hline \multicolumn{1}{c}{ Model } & \multicolumn{1}{c}{$\mathrm{CV}$} & $\mathrm{R}^{2}$ & $\mathrm{RMSE}$ & $\mathrm{N}_{0}$ & $\mathrm{~N}_{\mathrm{e}}$ & $\mathrm{h}$ & $\mathrm{K}$ \\
\hline 1st order rate & -36.3 & 0.9827 & 397 & $-9.27 \mathrm{E}-$ & $2.00 \mathrm{E}+22$ & & $-5 \mathrm{E}+21$ \\
Consecutive $(\mathrm{h} \neq \mathrm{k})$ & -5.58 & 0.9879 & 165 & 430.9 & & -0.644 & 0.2269 \\
Consecutive $(\mathrm{h}=\mathrm{k})$ & 36.3 & 0.9827 & 398 & $1.90 \mathrm{E}-21$ & $5.00 \mathrm{E}+23$ & -1.02 & 0.0954 \\
Gompertz & 0.535 & 0.9988 & 52.5 & 568.4 & -0.09 & 0.8116 \\
Mixed order rate & 7.36 & 0.9915 & 28.4 & $4.27 \mathrm{E}+02$ & & \\
\hline
\end{tabular}

LEGEND: $\mathrm{CV}=$ Coefficient of Variation; $\mathrm{R}^{2}=$ Coefficient of Determination; RMSE = Root Mean Square Error; $\mathrm{N}_{0}=$ potentially mineralized $\mathrm{N}$ at time 0 in $\mathrm{mg} \mathrm{kg}^{-1} \mathrm{~N}_{\mathrm{e}}=$ Additional term to accommodate the initial rapid $\mathrm{N}$ flush in $\mathrm{mg} \mathrm{kg}^{-1} ; \mathrm{h}$ and $\mathrm{k}$ are constants. 


\section{CONCLUSIONAND \\ RECOMMENDATIONS}

The results of this study would suggest that, for the purpose of describing $\mathrm{N}$ mineralization pattern from neem residue, a Gompertz function and a mixed order rate model were adequate. The two models recognize that $\mathrm{N}$ mineralization is not only a function of substrate $\mathrm{N}$ concentration but also of the capacity of the microbial community to adjust to substrate quality and composition affecting their growth and activity Further studies are necessary to clarify the plant nutrient uptake and the nutrient dynamics in field soils amended with neem seed cake.

\section{REFERENCES}

Adegbite E. A. and Olayinka, A. 2010. Effects of organic amendments and nitrogen on microbial activity, nitrogen and phosphorus mineralization in an alfisol. Nig. J.

Soil Sci. 20 (2): 87-91.

Agbenin, J. O.,Agbaji, E. B., Suleiman, I. and Agbaji, A. S. (1999). Assessment of nitrogen mineralization potential and availability from neem seed residue in a savanna soil. Boil. Fertil. Soils 29: 408412.

Agbenin, J. O., Ibitoye, S. O. and Agbaji, A. S. (2008). Nutrient mineralization from

deoiled neem seed in a savanna soil from Nigeria. Commun. Soil Sci. Plt. Analysis 39: 527-537.

Agehara, S. and Warncke, D. D. 2005. Soil moisture and temperature effects on nitrogen release from organic sources. Soil Sci. Soc. Am. J., 69: 1844-1855.

Andren, O. and Paustian, K. 1987. Barley straw decomposition in the field. Comparison of models. Ecology 68: 1190-1200.

Antonopoulos, V. Z. 1999. Comparison of different models to simulate soil temperature and moisture effects on nitrogen mineralization in the soil. $J$. Plant Nutr. Soil Sci., 162: 667-675.

Brunner, W. and Focht, D. D. 1984. Deterministic three-half-order kinetic model for microbial degradation of added carbon substrates in soil. Appl. Environ. Microbiol. 47: 162-167.

Carlyle, J. C. and Malcoln, D. C. 1986. Nitrogen availability beneath pure spruce and mixed larch + spruce stands growing on a deep peat. I. Net mineralization measured by field and laboratory incubations. Plant Soil 93: 95-113.

Cassman, K. G. and Munns, D. M. 1980. Nitrogen mineralization as affected by soil moisture, temperature and depth. Soil Sci. Soc. Am. J., 44: 1233-1237.

Diaz-Firroz, F., Carmen Villar, M., Gil, F., Carballas, M., Carmen Leiros, M., Tarsy

Carballas, and Ana Cabaneiro. 1988. Effect of cattle slurry fractions on nitrogen mineralization in soils. J. Agric. Sci. 110: 491-497.

Ellert, B. H. and Bettany, J. R. 1988. Comparison of kinetic models for describing net sulphur and nitrogen mineralization. Soil Sci. Soc. Am. J. 52: 1692-1702.

France, J. and Thornley, J. H. M. (1984). Mathematical models in agriculture. London: Butterworth and Co. Ltd.

Garba, J. 2010. Effect of neem seed cake and inorganic fertilizer on soil fertility and productivity of maize in a savanna alfisol. M.Sc. Thesis. Dept. Soil Sci., Ahmadu Bello University, Zaria.

Harmsen, G. W. and van Schreven, D. A. 1955. Mineralization of organic nitrogen in soil. Adv. Agron. 7: 299.

Hart, S. C. and Binkley, D. 1985. Correlations among indices of forest soil nutrient availability in fertilized and unfertilized loblolly pine plantations. Plant and Soil 85: 11-21.

Heal, O. W., Anderson, J. M. and Swift, M. J. 1997. Plant litter quality and ecomposition: An historical overview. p. 3-30. In G. Cadisch and K. Giller (ed.) Driven by nature: Plant litter quality and decomposition. Wallingford, England: CAB Int.

Idris, S. O., Agbaji, E. B., Agbaji, A. S. and Agbenin, J. O. 1995. Nitrogen mineralization in soil incubated with neem cake. J. Chem. Soc. Nig. 20: 2327.

Jones, C. A. 1984. Estimation of an active fraction of soil nitrogen. Comm. Soil Sci. Plant Anal., 28: 1359-1373.

Kenney, D. R. 1982. Nitrogen-availability indices. In: Page, A. L., Miller, R. H., Keeney, D. R. (ed). Methods of soil analysis: Part 2. Chemical and microbiological properties, $2^{\text {nd }}$ edn. Madison, Wisconsin: Am. Soc. Agron., Soil Sci. Soc., 711- 733.

Kethar, C. M. and Kethar, M. S. 1995. Neem seed crush and deoiled cake as manure and as nitrification inhibitors. In: Schmutterer, H. (ed). The neem tree. VCH, New York, pp 531-540

Kethar, C. M. (1974). Neem cake blended urea for nitrogen economy. Fertilizer News, 19: 25-26. 
Knoepp, J. D. and Swank, W. T. (1995). Comparison of available soil nitrogen assays in control and burned forested sites. Soil Sci. Soc. Am. J. 59: 17501754.

Lamb, D. 1980. Soil nitrogen mineralization in a secondary rainforest succession. Oecologia 47: 257-263.

Mokwunye, A. V. 1991. Alleviating soil fertility constraints to increase crop production in West Africa. Netherlands: Kluwer Academic Publishers.

Murwira,H. K., Mutuo, P., Nhamo, N., Marandu, A. E., Rabeson, R., Mwale, M. and Palm, C. A. (2002). Fertilizer equivqlency values of organic materials of differing quality. In: intergrated plant nutrient management in subSaharan Africa, Vanlaume, B., Diels, J., Sanginga, N. and Merckx, R. (eds.). CAB International, pp. 113-122.

Noggle, J. H. (1985). Physical chemistry. In Ellert, B. H. and Bettany, J. R. (1988).

Comparison of kinetic models for describing net sulphur and nitrogen mineralization.Soil Sci. Soc. Am. J. 52:1692-1702

Radwanski, S. A. (1969). Improvement of acid soil by neem trees (Azadirachta indica) in Sokoto, north western state of Nigeria. J. of Applied Ecology 6: 507511
Raison, R. J., Connell, M. J. and Khanna, P. K. (1987). Application of sequential soil coring and in situ incubations to the study of N-cycling in plant communities. In Nitrogen cycling in agricultural systems of temperate Australia.Australian Society of Soil Science, Wagga Wagga.

Singh, R. P., Singh, P. P., and Nair, K. P. P. 1991. Studies on controlled release of N fertilizers and nitrification inhibitors. Indian J. Agric. Res. 25: 59-62.

Stanford, G. and Smith, S. J. 1972. Nitrogen mineralization potentials of soils. Soil Sci. Soc. Am. Proc., 36: 465-472.

Swift, M. J., Heal, O.W. and Anderson, J. M. (1979). Decomposition in terrestrial ecosystems. Studies in ecology. Vol. 5. England, Oxford: Blackwell scientific.

Uyovbisere, E. O., Elemo, K. A. and Tarfa, B. D. 1999. Effect of foliage of locust bean and neem on soil fertility and productivity of early maize in a savanna Alfisol. In: Impact, challenges and prospects of maize research and development in West and Central Africa. WECAMAN/ IITA workshop proceedings pp. 185-194

Vandepitte, V., Quartaert, P., DeRore, H., and Verstraete, W. 1995. Evaluation of the Gompertz function to model survival of bacteria introduced into soils. Soil Biol. Biochem. 27: 365-372.

Vietmeyer, N. D. (1992). Neem: A tree For solving global problems. Washington, DC: National academy press. 